DOI: 10.18276/sip.2018.54/3-14

\title{
Józef Hozer*
}

Uniwersytet Szczeciński

\section{PROPORCJONALNOŚĆ W EKONOMII}

\section{Streszczenie}

Celem artykułu jest omówienie znaczenia proporcjonalności w ekonomii. Zjawiska w ekonomii mogą występować w relacji powiązania (przyczynowo-skutkowego, celowego, współistnienia) lub współwystępowania. W ekonomii używanych jest wiele wskaźników i współczynników dla opisywania dwóch zjawisk. W artykule omówiono trzy autorskie miary proporcjonalności: współczynnik proporcji między liczbą gospodarstw domowych a liczbą podmiotów gospodarczych w danym kraju, regionie, wskaźnik wartości rynkowej nieruchomości, wskaźnik siły skłonności.

Słowa kluczowe: proporcjonalność powiązania, współwystępowanie

\section{Wstęp}

W teorii i praktyce ekonomicznej często rozpatrujemy relację:

$$
Y_{i}=\alpha X_{i}+u_{i}
$$

gdzie:

$\alpha$ jest parametrem proporcjonalności między zjawiskiem $Y_{i}$ i $X_{i}$, $u_{i}$ w sensie ekonometrycznym stanowi składnik losowy.

* Adres e-mail: Jozef.Hozer@usz.edu.pl. 
Zjawiska $Y_{i}$ i $X_{i}$ mogą występować w relacji powiązania' (związek przyczynowo-skutkowy, związek celowy, związek współistnienia) lub tylko współwystępowania². Zjawiska mogą być niepowiązane, tylko współwystępujące, ale analityczne zestawienie relacji proporcji może być pouczające, na przykład badamy ilość produkowanej energii atomowej w kraju A i kraju B. Z tej relacji może wynikać cały szereg reperkusji, na przykład kraj o dużej produkcji energii atomowej może łatwiej akceptować restrykcje w zakresie zwalczania emisji gazów do atmosfery. Natomiast dla kraju o małej produkcji energii atomowej, ale zużywającego znaczne ilości węgla, takie restrykcje mogą być dokuczliwe.

Relacja (1) zarówno w formie powiązania, jak i formie współwystępowania może odgrywać ważną rolę $\mathrm{w}$ analizowaniu i diagnozowaniu w ekonomii.

Jeżeli chodzi o relację współwystępowania zjawisk w ekonomii, to mogą one spełniać głównie rolę analityczno-diagnostyczną. Porównywanie dwóch zjawisk za pomocą relacji proporcjonalności jest praktykowane powszechnie w teorii i praktyce gospodarczej.

Jeżeli relację (1) potraktujemy jako model ekonometryczny, to parametr $\alpha$ może być szacowany na wiele sposobów. W pracy (Hozer, 1996a) wykazano, że najlepsze własności w sensie statystycznym ma estymator według metody najmniejszych kwadratów:

$$
\widehat{\alpha}=\frac{\sum y_{i} x_{i}}{\sum x_{i}^{2}},
$$

Przyjmując (1) jako relację proporcjonalności, zakładamy, że ma ona charakter niedeterministyczny, co zwykle ma miejsce w praktyce. $Z$ tego też względu w teorii i praktyce ekonomicznej stosowane są między innymi następujące miary:

- wskaźnik płynności bieżącej (domena analizy finansowo-ekonomicznej),

- wskaźnik płynności szybkiej,

- rentowność sprzedaży,

- rentowność zatrudnienia,

- wskaźnik rotacji zapasów,

- stopa zysku,

- wskaźnik struktury kosztów rodzajowych,

1 Przykładem może być: związek produkcji i kosztów w przedsiębiorstwie, liczba podmiotów gospodarczych oraz liczba gospodarstw domowych w gospodarce, liczba kobiet i liczba mężczyzn w kraju itp.

2 Przykładem może być: produkcja i czas w przedsiębiorstwie, inwestycje i aktywa trwałe w przedsiębiorstwie, liczba pracowników w przedsiębiorstwie A i liczba pracowników w przedsiębiorstwie B, przewóz towaru oraz produkcja towaru itp. 
- wskaźnik struktury kosztów kalkulacyjnych,

- wskaźnik zadłużenia,

- wskaźnik struktury aktywów,

- wskaźnik struktury pasywów,

- wskaźnik odnowienia majątku,

Cały szereg tych stosowanych miar ma taki charakter z powodu indeterministycznego lub deterministycznego (niedokładna relacja matematyczna, błędy w pomiarze itp.). Wszystkie te miary weszły na stałe do kanonu analiz finansowo-ekonomicznych przedsiębiorstwa (lub przedsięwzięcia); są szeroko eksplorowane w literaturze ekonomicznej.

W niniejszym opracowaniu poruszamy trzy rzadko używane wskaźniki:

a) wskaźnik proporcjonalności między liczbą gospodarstw domowych i liczbą podmiotów gospodarczych w kraju;

b) wskaźnik wartości rynkowej nieruchomości mierzący efekty wpływu na wartość nieruchomości takich elementów rynku, jak na przykład:

- efekt nierównowagi rynkowej,

- moda,

- wpływ lokalizacji itp.;

5. wskaźnik skłonności, gdy poprzez skłonność rozumiemy nachylenie kogoś lub czegoś do kogoś lub czegoś (zob. Hozer, Doszyń, 2004).

\section{Quantum satis}

Quantum satis (łac.) oznacza ilość wystarczającą. Może być użyte też w znaczeniu właściwa proporcja. Okazuje się, że porównując dwa zjawiska, konstruujemy wskaźniki i współczynniki proporcjonalności. W pracach (Hozer, 1996a; Hozer-Koćmiel, Hozer, 2012; Hozer, Hozer, 1989; Hozer, 1996b, 1975) autorzy rozważają proporcję pomiędzy liczbą gospodarstw domowych a liczbą podmiotów gospodarczych w gospodarce, regionie, aglomeracji, wywodząc wniosek, że liczba podmiotów gospodarczych (firm i farm) pozostaje w ważnej proporcji do liczby gospodarstw domowych i na jeden podmiot gospodarczy $\mathrm{w}$ danym kraju³ powinno przypadać najwyżej pięć

3 Rozpatrujemy proporcję $Y=\alpha X$, gdzie $Y$ jest to liczba gospodarstw rodzinnych w danym kraju, $X$ to liczba podmiotów gospodarczych. Jest dobrze, gdy $\alpha=5$. W Polsce w $1987 \mathrm{r}$. $\alpha$ równało się 21 (zob. Hozer, 1996b), a w 2016 r. współczynnik proporcjonalności $\alpha$ był na poziomie 4,1 (zob. Hozer, Machała, 2017). 
gospodarstw domowych. Liczba pięć traktowana jest jako quantum satis. Jak pokazuje praktyka, taką proporcję osiąga coraz więcej państw. Wyniki przedstawiono w tym względzie w pracach: (Hozer, Machała, 2017; Hozer, 1996a; Hozer-Koćmiel, Hozer, 2012; Hozer, Hozer, 1989).

W pracy (Hozer, 1996b) przedstawiono tablicę z badaną relacją $\alpha=\frac{Y}{X}$ dla wybranych dziewięciu państw (w latach 1983-1987). Widzimy, że normę osiągały tylko kraje wysoko rozwinięte.

Tabela 1. Relacja wyrażona współczynnikiem proporcjonalności $\alpha$ między liczbą gospodarstw domowych i liczbą firm w wybranych krajach

\begin{tabular}{|l|c|c|c|c|c|c|c|c|c|}
\hline Kraj & Szwecja & Włochy & Japonia & Francja & USA & Polska & Węgry & NRD & ZSRR \\
\hline Rok & 1986 & 1987 & 1986 & 1983 & 1987 & 1986 & 1986 & 1987 & 1987 \\
\hline$\alpha$ & $\mathbf{4 , 7 6}$ & $\mathbf{6 , 5 3}$ & $\mathbf{5 , 3 2}$ & $\mathbf{5 , 6 8}$ & $\mathbf{5 , 1}$ & $\mathbf{2 1 , 2}$ & $\mathbf{2 0 , 1}$ & $\mathbf{2 0 , 6}$ & 93,9 \\
\hline
\end{tabular}

Źródło: Hozer (1996b).

W pracy (Hozer, Machała, 2017) przedstawiono, jak badana relacja zmieniała się w takich krajach, jak Rosja i Chiny, w latach 2010-2016.

Tabela 2. Relacja wyrażona współczynnikiem proporcjonalności $\alpha$ między liczbą gospodarstw domowych i liczbą firm w Chinach i w Rosji w latach 2010-2016

\begin{tabular}{|l|c|c|}
\hline \multicolumn{1}{|c|}{ Rok } & $\alpha$ dla Chin & $\alpha$ dla Rosji \\
\hline 2010 & 7,64 & 7,00 \\
\hline 2011 & 5,89 & 6,71 \\
\hline 2012 & 5,64 & 6,38 \\
\hline 2013 & 5,72 & 6,22 \\
\hline 2014 & 5,59 & 5,83 \\
\hline 2015 & 5,58 & 5,38 \\
\hline 2016 & 5,55 & 5,00 \\
\hline
\end{tabular}

Źródło: Hozer, Machała (2017).

Sformułowanie: właściwa proporcja dla relacji:

$$
\mathbf{Y}=\alpha \mathbf{X}
$$

wynika z funkcji diagnostycznej narzędzi ilościowych (statystyczno-ekonometrycznych). Narzędzia ilościowe w ekonomii mogą mieć funkcje analityczno-opisowe, diagnostyczno-kontrolne i planistyczno-prognostyczne.

Funkcja diagnostyczna od funkcji prognostycznej różni się tym, że ta pierwsza dotyczy oceny zjawiska ex post, a ta druga odnosi się do przewidywania ex ante. 
W przypadku diagnozy mówimy o realizacji $Y$, normie $Y^{N}$ i tolerancji dla odchylenia:

$$
\Delta N=Y-Y^{N} .
$$

Skąd czerpać normy dla realizacji zjawisk? Tak jak w medycynie wiemy, jaka jest norma ciśnienia u zdrowego człowieka, tak i w ekonomii wiemy, jaka jest norma płynności finansowej dla zdrowego przedsięwzięcia (przedsiębiorstwa).

Skąd można czerpać wiedzę o normach w ekonomii?

Po pierwsze, z badań „klinicznych”. Wyniki pomiaru (wskaźniki, współczynniki, absolutne wartości) badanego podmiotu gospodarczego porównujemy z wynikiem pomiaru w podmiocie uznanym za wzorcowy.

Po drugie, z teorii ekonomii. Norm dla pomiarów zjawisk w teorii nie ma zbyt wiele. Wynika to z tego, że ekonomiści usilnie dążą do ulepszania narzędzi przewidywania zjawisk ekonomicznych. Nie poświęcają zbyt dużo uwagi funkcji diagnostycznej, która może mieć duże znaczenie dla teorii i praktyki gospodarczej.

\section{Wskaźnik wartości rynkowej}

Drugim analizowanym przypadkiem jest wskaźnik wartości rynkowej, którego używamy w tak zwanym algorytmie szczecińskim do wyceny nieruchomości gruntowej w sposób elektroniczny (zob. Hozer, 1999).

Sposób postępowania jest następujący:

a) ustalamy zbiór nieruchomości gruntowych;

b) przeprowadzamy identyfikację atrybutów (np. wielkość, dostępność, sąsiedztwo, uzbrojenie);

c) dywersyfikujemy zbiór działek do wyceny w jednorodne podzbiory pod względem wielkości, dostępności, sąsiedztwa, uzbrojenia itp.;

d) na część z działek w poszczególnych podzbiorach wysyłamy rzeczoznawców, którzy wyceniają wartość rynkową nieruchomości;

e) rzeczoznawcy przeprowadzają kalibrację atrybutów (np. wielkość, dostępność, sąsiedztwo itp.);

f) tworzona jest macierz A;

g) dla każdego obrębu obliczamy wskaźnik $\widehat{W W R_{i}}$ według reguły:

$$
\widehat{W W R_{i}}=\frac{W_{r z_{i}}}{\operatorname{pow}_{b_{b a z} \cdot \prod_{i}\left(1+\widehat{A}_{i}\right)}}
$$


gdzie:

$W_{r z_{i}}$ - wartość nieruchomości oszacowana przez rzeczoznawców, pow - powierzchnia działk, $C_{b a z}$ - cena bazowa $1 \mathrm{~m}^{2}$ nieuzbrojonego najtańszego gruntu rolnego, $\hat{A}_{i}$ - skalibrowane wartości przypisane konkretnym atrybutom nieruchomości; są one określane przez rzeczoznawców na podstawie analiz rynku lokalnego i odzwierciedlają siłę wpływu poszczególnych atrybutów na wartość nieruchomości.

Wartość nieruchomości $\widehat{W}_{i}$ obliczamy z modelu:

$$
\widehat{W}_{i}=\widehat{W W R_{i}} \cdot \operatorname{pow}_{i} \cdot C_{b a z} \cdot \prod_{i}\left(1+\widehat{A}_{i}\right),
$$

Wskaźnik $\widehat{W W R}_{i}$ określa, o ile wyższa jest wartość $1 \mathrm{~m}^{2}$ wycenionego gruntu w stosunku do hipotetycznej wartości $1 \mathrm{~m}^{2}$ (gruntu nieuzbrojonego, nieodrolnionego) znajdującego się na danym terenie elementarnym. $\widehat{W W R_{i}}$ wycenia wpływ atrybutów rynkowych (popyt, podaż, moda itp.) na wartość nieruchomości (por. Hozer, 1999).

Algorytmu tego użyto do wyceny 16 tys. działek położonych na 250 terenach elementarnych w Szczecinie w 1998 roku. Okazało się, że algorytm z użyciem $\widehat{W W R}_{i}$ pozwolił na prawie dokładną wycenę 500 działek reprezentantek. W pracy (Hozer, 1999, s. 59) przedstawiono rozkłady częstości wartości $1 \mathrm{~m}^{2}$ działek wycenianych przy użyciu algorytmu i rozkładu częstości wartości $1 \mathrm{~m}^{2}$ tych samych działek wycenionych przez rzeczoznawców w sposób tradycyjny. Wskaźnik $\widehat{W W R_{i}}$ jest relacją proporcjonalności pomiędzy wartościami $W_{r z_{i}}$ i wartościami wyliczonymi za pomocą wzoru: $\operatorname{pow}_{i} \cdot C_{b a z} \cdot \prod_{i}\left(1+\hat{A}_{i}\right)$.

\section{Miara siły skłonności}

Trzecim przykładem, który zamierzamy omówić w kontekście relacji proporcjonalności, jest badanie skłonności. Skłonność to nachylenie czegoś lub kogoś do czegoś lub kogoś, które sprawia, że prawdopodobieństwo zdarzenia może być większe.

Jeżeli przez $A$ oznaczymy frakcję zdarzeń, gdzie nie występuje dane zjawisko, to relację:

$$
\mathrm{SK}=\operatorname{tg} \alpha=\frac{1-A}{A}
$$

nazwiemy miarą skłonności.

Za pracą (Hozer, Doszyń, 2004, s. 35) zaprezentujemy badane skłonności $\mathrm{w}$ formie graficznej. 
Rysunek 1. Graficzna prezentacja siły skłonności

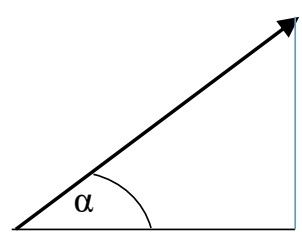

A

$1-\mathrm{A}$

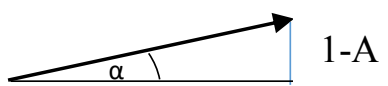

A

Mała siła skłonności

Duża siła skłonności

Źródło: opracowanie własne.

SK może przyjmować wartości zarówno mniejsze od jedności, jak i większe. Zależy to od siły skłonności.

O silnej skłonności możemy mówić przy:

$$
\mathbf{0} \leq \boldsymbol{S K}<\mathbf{1}
$$

a o skłonności umiarkowanej mówimy, gdy:

\section{$S K \geq 1$.}

W przypadku ludzi możemy mówić o trzech zasadniczych rodzajach skłonności: duchowych, materialnych i biologicznych. Znajomość tych skłonności może sprzyjać podejmowaniu dobrych decyzji w procesie zarządzania kapitałem ludzkim. To z kolei wpływa na efektywność tego kapitału. Zjawisko skłonności odnieść można również do rzeczy, zwierząt itp.

\section{Podsumowanie}

W niniejszym opracowaniu poruszono zagadnienia związane z trzema rzadko stosowanymi wskaźnikami, które mogą być bardzo przydatne w ustaleniu norm ekonomicznych, a także w diagnozowaniu zjawisk ekonomicznych. Są to:

a) wskaźnik proporcjonalności między liczbą gospodarstw domowych i liczbą podmiotów gospodarczych w kraju;

b) wskaźnik wartości rynkowej nieruchomości mierzący efekty wpływu na wartość nieruchomości takich elementów rynku, jak na przykład efekt nierównowagi rynkowej, moda czy wpływ lokalizacji;

c) wskaźnik siły skłonności. 
Badanie tych wskaźników może być przydatne zarówno dla naukowców prowadzących badania ekonomiczne (analizy, diagnozy i prognozy), jak i dla praktyków ekonomii.

\section{Literatura}

Hozer, J. (1975). O badaniu proporcjonalności zmiennych. Przeglad Statystyczny, XXII (1), $147-158$.

Hozer, J. (1996a). Celowość działań jako ważny element zakłócający w badaniu ekonometrycznym dla danych w postaci szeregów czasowych. Przegląd Statystyczny, XLIII (1-2), $77-81$.

Hozer, J. (1996b). Poszukiwanie norm proporcji gospodarczych. Przeglad Statystyczny, XLIII (1-2), 9-14.

Hozer J. (red.) (1999). Ekonometryczny algorytm masowej wyceny nieruchomości gruntowych. Szczecin: Katedra Ekonometrii i Statystyki US.

Hozer, J., Doszyń, M. (2004). Ekonometria skłonności. Warszawa: PWE.

Hozer, E., Hozer, J. (1989). Przyczyny i skutki kryzysu gospodarczego w Polsce. Wektory Gospodarki, 5, 11-16.

Hozer, J., Machała, S. (2017). Weryfikacja typowej proporcji między liczbą gospodarstw domowych a liczbą przedsiębiorstw (quantum saris) dla wybranych krajów. Wiadomości Statystyczne, 7, 18-24.

Hozer-Koćmiel, M., Hozer, J. (2012). Proporcje liczby podmiotów gospodarczych, gospodarstw rolnych i gospodarstw domowych. Wiadomości Statystyczne, 11, 13-21.

Sierpińska, M., Jachna, T. (1997). Ocena przedsiębiorstwa wedlug standardów światowych. Warszawa: Wyd. Naukowe PWN. 


\title{
PROPORTIONALITY IN ECONOMICS
}

\begin{abstract}
The purpose of this article is to discuss the importance of proportionality in economics. Phenomena in economics can occur in the relationship of connection (cause-effect, purpose, coexistence) or co-occurrence. Many indicators and coefficients are used in economics to describe two phenomena. The article describes three original measures of proportionality: the ratio of the number of households to the number of economic entities in a given country or region, the market value indicator, the propensity indicator.
\end{abstract}

Translated by Jozef Hozer

Keywords: proportionality of connection, co-occurrence JEL Codes: C10, D01, R31 